\title{
Muscle fuel selection: effect of exercise and training
}

\author{
BY JAN HENRIKSSON \\ Department of Physiology and Pharmacology, The Karolinska Institute, Stockholm, Sweden
}

\section{Sélection des substrats énergétiques du muscle: effet de l'exercice et de l'entrainement}

\begin{abstract}
RÉSUMÉ
Les cellules des muscles du squelette ont une capacité tout à fait remarquable d'adaptation aux modifications de la demande métabolique. Ces modifications dues à l'adaptation ont des conséquences sur la sélection des substrats énergétiques des muscles qui travaillent, et donc sur toute l'homéostase du corps pendant l'exercice et dans la période qui suit. Cette revue porte sur les principaux progrès accomplis dans ce domaine de recherche au cours de ces dernières années. Avec l'entraînement à l'endurance, l'importance du glucose plasmatique comme substrat énergétique dans l'exercice diminue. Ceci n'est pas inattendu étant donné qu'il est bien connu que le recours au métabolisme des graisses augmente chez le sujet entraîné, mais il est difficile de concilier ce fait avec des rapports selon lesquels l'entraînement à l'endurance produit une augmentation du nombre des molécules de transport du glucose dans le muscle du squelette. Ceci indique que cette dernière adaptation sert d'autres objectifs, comme celui de permettre l'augmentation de la sensibilité à l'insuline, et également de la réponse à celle-ci observée après l'entraînement à l'endurance. Un autre facteur important sous-jacent à cette augmentation de l'action de l'insuline dans le muscle entraîné semble bien être l'augmentation de l'activité de la glycogène synthase ( $E C$ 2.4.1.11), et il est bien documenté que les individus entraînés ont une plus grande capacité de stocker le glycogène. De plus, d'autres mécanismes susceptibles d'augmenter l'action de l'insuline ont été discutés, parmi lesquels une augmentation de l'effet de l'insuline pour stimuler le flux sanguin du muscle, une augmentation de la liaison de l'insuline du tissu due à une plus grande capillarisation dans le muscle entraîné, et des modifications dans la composition des acides gras dans le sarcolème du muscle. L'entraînement réduit la dégradation du glycogène pendant l'exercice, le plus grand effet se produisant au début de l'exercice, et ceci pourrait finalement expliquer la diminution de l'utilisation de glucose dérivé du plasma. Il est concevable qu'un facteur majeur derrière cette économie du glycogène est l'augmentation adaptative des mitochondries du muscle. Des données récentes indiquent que l'utilisation des graisses au cours de l'exercice plus élevée chez le sujet entraîné que chez le sujet non entraîné est alimentée par une plus grande lipolyse de triacylglycérols intramusculaires, et que le taux de renouvellement des acides gras libres du plasma est inférieur chez les individus entraînés. Il est possible que le triacylglycérol soit un substrat énergétique important pour le muscle du squelette en contraction, en particulier au cours de l'exercice dans l'état d'absorption. Les études sur la lipase lipoprotéinique ( $E C$ 3.1.1.34) des tissus indiquent que le triacylglycérol circulant peut
\end{abstract}


être plus important chez le sujet entraîné que chez le sujet non entraîné. Au cours de l'exercice prolongé, le métabolisme des acides aminés à chaîne ramifiée est activé, et probablement à un degré plus élevé chez les individus entraînés. Ce domaine de la recherche est actuellement dans une phase active, et ce n'est que récemment qu'on a commencé à découvrir l'implication de plusieurs facteurs auparavant non identifiés, tels que le facteur de croissance 1 semblable à l'insuline dans l'absorption du glucose induite par la contraction.

The contracting skeletal muscle relies on fuels from both extra- and intramuscular sources. The main stored fuels are glycogen and triacylglycerols (TG). The largest muscle store of potentially energy-yielding fuels, i.e. the muscle proteins themselves, normally contributes very little to the total energy expenditure in skeletal muscles. Nevertheless, amino acids are important molecules in the metabolic regulation of contracting muscle. Glucose and non-esterified fatty acids (NEFA) are important blood-borne fuels utilized by skeletal muscle. Circulating TG are believed to play a minor role, but their importance may have been underestimated in the past. Ketone bodies are taken up by skeletal muscle, but to a very low extent. It is well documented that training induces an increased reliance on fat relative to carbohydrate metabolism. In the resting state, skeletal muscle is important as the body's largest insulin-sensitive organ; an impaired insulin sensitivity in skeletal muscle is associated with cardiovascular disease. Contractile activity induces an increased muscle sensitivity to insulin, which usually lasts $1-2 \mathrm{~d}$.

The present review focuses on the major advances made in this research area during the last few years.

\section{RELATIVE IMPORTANCE OF THE DIFFERENT SUBSTRATES FOR ENERGY DELIVERY DURING EXERCISE}

Generally, the reliance on carbohydrates as an energy source increases with the exercise intensity and with the relative amount of carbohydrates in the pre-exercise diet and decreases with the fitness level of the individual. The relative importance of blood-borne $v$. endogenous substrates is, among other factors, dependent on the time interval that has passed since the last meal and on the extent of depletion of endogenous glycogen subsequent to previous exercise.

\section{Plasma-derived glucose}

Oxidation of plasma-derived glucose may represent a significant portion of the fuel for muscular exercise. At rest, only a small percentage of the muscle fuel is made up of carbohydrates and this consists almost entirely of plasma glucose (Wahren et al. 1971). During exercise, the importance of carbohydrate increases considerably. Wahren et al. (1971) observed that plasma-derived glucose accounted for $10-30 \%$ of the total substrate oxidation by the leg muscle during the initial period of light to moderate exercise. Endogenous glycogen is the dominant fuel during the initial period of moderate to severe exercise, and during sustained exercise at work rates corresponding to about $60-80 \%$ $V_{\mathrm{O}_{2} \max }$ fatigue coincides with the depletion of muscle glycogen (Bergström et al. 1967; 
Sherman \& Costill, 1984). With the continuous depletion of endogenous glycogen, the utilization of plasma-derived glucose increases and has, during prolonged exercise, been reported to amount to $75-90 \%$ of the estimated carbohydrate oxidation by muscle (Wahren et al. 1971).

\section{Plasma-derived non-esterified fatty acids}

Plasma-derived NEFA are the dominant fuel in muscle at rest and have been estimated to correspond to $80 \%$ of the $\mathrm{O}_{2}$ uptake in resting muscle (Havel et al. 1967). During exercise at low to moderate intensities plasma NEFA may often cover more than half the muscle's oxidative metabolism, especially during prolonged exercise (Ahlborg et al. 1974), but its importance diminishes as the exercise intensity increases.

\section{Plasma triacylglycerols}

Plasma TG has been considered to contribute very little to exercise metabolism (Havel et al. 1967; Jones et al. 1980). In a study where forty army recruits were fed on $55 \mathrm{~g}$ fat after an $11 \mathrm{~h}$ fast, Nikkilä \& Konttinen (1962) found that during an ensuing $2 \mathrm{~h}$ march only $4 \%$ of the energy required for the work could have been provided by the circulating TG. However, Nikkilä \& Konttinen (1962) state that possible hepatic TG synthesis was not accounted for, and this could have led to underestimation of the recorded plasma $\mathrm{TG}$ utilization. In fact, the decrease in plasma TG after exercise (Oscai et al. 1990), reduction of postprandial lipidaemia during and after exercise (see Griffiths et al. 1994) and preferential uptake of chylomicron TG by oxidative fibres in contracting rat muscle, compared with fast-twitch fibres (Mackie et al. 1980), all suggest that plasma TG may be an important fuel for contracting muscle.

It should be mentioned that most investigations in this area are performed in the postabsorptive state after an overnight fast. The metabolic situation during more everyday situations is evidently quite different, for example plasma NEFA are less important in the fed state than 8-10 h after the last meal (Havel et al. 1963). In the postabsorptive state glucose uptake during $60 \mathrm{~min}$ of forearm exercise could account for $40 \%$ of the energy demand; if the same exercise was undertaken $3 \mathrm{~h}$ after a meal there was no change in the contribution of plasma glucose but the increased uptake of TG could account for $40 \%$ of energy demand. Also there was a net uptake of free fatty acids (Griffiths et al. 1994).

Due to the high blood flow during exercise, arterio-venous (A-V) differences for VLDL-TG are very difficult to detect accurately (Kiens et al. 1993), but it has been estimated that, if oxidized, plasma TG could account for half muscle TG oxidation during exercise (Kiens et al. 1993).

\section{Endogenous triacylglycerols}

Relatively little is known about this potential source of energy for the contracting muscle, but it seems likely to be an important fuel during exercise. During $99 \mathrm{~min}$ of cycle ergometer exercise to exhaustion, Carlson et al. (1971) found that the decrease in thigh muscle TG concentration averaged $25 \%(n 24)$. They calculated that $70 \%$ of total oxidized fatty acids originated from endogenous TG, whereas $30 \%$ came from plasma NEFA, and that the energy contribution of endogenous TG was $70 \%$ of that of glycogen. 
Fröberg \& Mossfeldt (1971) calculated that during the Swedish $7 \mathrm{~h}$ Wasa ski race the decrease in muscle TG corresponded to twice the energy compared with the decrease in muscle glycogen. The findings of Hurley et al. (1986) are discussed later (see p. 130).

\section{MUSCLE GLUCOSE UPTAKE}

Glucose is transported into mammalian skeletal muscle by a glucose transporter. The most abundant glucose transporter in mammalian skeletal muscle is the insulin-regulated glucose transporter, GLUT4. A second isoform of the glucose transporter (GLUT1) has also been isolated from skeletal muscle. Recent data on transgenic mice overexpressing GLUT1 or GLUT4 protein support the concept that GLUT1 contributes mainly to basal glucose transport, whereas GLUT4 is responsible for the increased glucose uptake mediated by insulin or contractile activity (Marshall et al. 1993; Robinson et al. 1993). Glucose uptake following a single bout of exercise appears to be enhanced by an increase in both the number of transporters and transporter activity (Douen et al. 1989; Sternlicht et al. 1989; Goodyear et al. 1990).

During the last few years it has become evident that insulin-like growth factor 1 has a key role in stimulating increased glucose uptake in the contracting muscle (Dimitriadis et al. 1992) and quite recently it was proposed that stimulation of sarcolemmic adenosine receptors during contractions is also involved in the stimulation of muscle glucose transport (Vergauwen et al. 1994). Apart from stimulating the transport step, muscle contraction promotes the utilization of blood-derived glucose by increasing hexokinase binding to mitochondria (Van Houten et al. 1992). This may be a mechanism of coordinating the rate at which glucose is introduced into glycolysis with the rate of mitochondrial oxidative phosphorylation (BeltrandelRio \& Wilson, 1992). Unlike glucose, dietary fructose does not serve as a direct source of fuel for the muscle. Nevertheless, fructose feeding before or during exercise can enhance performance under certain conditions. For further discussion, see Craig (1993).

\section{Effect of training}

During a standardized $2 \mathrm{~h}$ exercise test, Coggan et al. (1990) estimated that $21 \%$ of the total energy expenditure was contributed by the oxidation of plasma glucose during 90-120 min of exercise. After 12 weeks of strenuous exercise training, this value had decreased to $15 \%$. This is not unexpected in the light of the increased reliance on fat metabolism in the trained state. However, it was unexpected that, also when expressed as a percentage of total carbohydrate oxidation, the reliance on plasma glucose decreased. These results are difficult to reconcile with the recent reports that endurance training leads to an increased number of glucose transporters owing to an increased synthesis of transporter protein (Dela et al. 1993; Ebeling et al. 1993). Jansson \& Kaijser (1987) found no effect, with training, on blood glucose extraction by the legs after $15 \mathrm{~min}$ of bicycle exercise at $65 \% V_{\mathrm{O}_{2} \max }$ but after $60 \mathrm{~min}$ of exercise, the blood glucose extraction was considerably lower in the trained than in the untrained subjects. At this time-point, blood glucose corresponded to only $5 \%$ of the total oxidative metabolism in the trained subjects compared with $23 \%$ for the untrained subjects. These authors suggested that the decreased blood glucose extraction by the legs of the trained subjects was secondary to the glycogen-sparing effect of training, resulting in a higher muscle 
glycogen concentration during the later stages of the exercise session. However, a recent study showed that also other adaptations must be responsible for the decreased blood glucose utilization following training (Mendenhall et al. 1994). These authors found evidence that altered plasma concentrations of the glucoregulatory hormones may be one such adaptation.

The low blood glucose utilization after training in the study of Coggan et al. (1990) may explain why the trained, unlike the untrained, subjects in this study were able to maintain or even increase their blood glucose concentration throughout the $2 \mathrm{~h}$ of exercise. A lower utilization of blood glucose during exercise in the trained state could explain the reduced liver glycogen depletion during exercise reported earlier in rats after training (Fitts et al. 1975).

\section{MUSCLE GLYCOGEN UTILIZATION}

Glycogen storage in skeletal muscle is a major limiting factor in prolonged performance, and accordingly preservation of these stores during exercise is of great importance. It was recently estimated that the total amount of carbohydrates used during a marathon race was higher than could be accounted for by the endogenous glycogen stores in the working muscles and the liver (O'Brien et al. 1993). The authors concluded that glycogen reserves in inactive muscle and other tissues must also have been mobilized. Glycogenolysis with net lactate release from inactive muscle has been demonstrated during exercise (Ahlborg et al. 1986).

Glycogen depletion is reduced during prolonged exercise in trained compared with untrained individuals working at the same absolute rate (the same rate of $\mathrm{O}_{2}$ consumption; Fitts et al. 1975), although the rate of glycogen depletion may be similar if the subjects are exercising at the same relative intensity (same percentage of $V_{\mathrm{O}_{2} \max }$ ) (Hermansen et al. 1967; Henriksson, 1991). In contrast, Jansson \& Kaijser (1987) demonstrated reduced glycogen utilization in the muscles of endurance-trained subjects when exercise was performed at the same relative intensity $\left(65 \%\right.$ of $\left.V_{\mathrm{O}_{2} \max }\right)$. These authors, and also Green et al. (1990), found that training exerts its greatest effect in reducing glycogen degradation early in exercise. Green et al. (1990) were also able to show that this effect occurs in both fast- and slow-twitch fibres.

Training can result in reduced muscle glycogen utilization during exercise in several ways. It is conceivable that a major factor is the adaptive increase in muscle mitochondria. A hypothetical biochemical mechanism whereby a large concentration of mitochondrial oxidative enzymes in trained muscle would lead to a greater reliance on fat metabolism, a lower rate of lactate formation, and sparing of muscle glycogen during exercise has been formulated by Holloszy and coworkers (Holloszy \& Booth, 1976).

\section{MUSCLE GLYCOGEN STORAGE}

Apart from a lower rate of glycogenolysis during exercise, trained individuals also have an increased glycogen storage capacity in skeletal muscle and in all probability a capacity for faster replenishment of muscle glycogen stores following exercise bouts (Mikines et al. 1989a; Kern et al. 1990). Particularly convincing evidence that local, and not only dietary, factors are responsible for this difference in storage capacity between trained and untrained muscle comes from studies of one-leg training (Saltin et al. 1976; 
Henriksson, 1977). This increased level of glycogen is, however, reduced to that of untrained muscle upon detraining or immobilization (Häggmark, 1978).

The increased storage capacity of muscle glycogen, which is found in trained skeletal muscle, is likely to be secondary to improved insulin action. In addition, muscle glycogen synthase (EC 2.4.1.11) activity is higher in trained individuals than in untrained ones (Ebeling et al. 1993), and athletes have increased whole-body insulin-stimulated glucose metabolism associated with both pre- (mRNA) and post-translational (enzyme activity) upregulation of glycogen synthase (Vestergaard et al. 1994). It is known that glycogen synthase is activated by insulin (Devlin \& Horton, 1985).

\section{UTILIZATION OF BLOOD-BORNE AND ENDOGENOUS LIPIDS}

It is known from a large number of studies that, at the same absolute exercise intensity, trained individuals rely more on fat as an energy substrate than untrained ones. The source of this increased fat supply has been debated, since the plasma levels of free fatty acids are often lower during exercise in endurance-trained subjects (Holloszy, 1988). Hurley et al. (1986) studied nine male subjects before and after a 12-week programme of endurance training. When exercising at the same absolute intensity $(64 \%$ of the pretraining $V_{\mathrm{O}_{2} \max }$ ), plasma free fatty acid and glycerol concentrations were found to be lower in the trained state than in the untrained state. In spite of this, the respiratory exchange ratio was reduced in the trained state, indicating a greater reliance on fat oxidation. Muscle TG utilization was found to be twice as great (26.1 (SD 9.3) v. $12 \cdot 8$ (SD $5.5) \mathrm{mmol} / \mathrm{kg}$ dry weight) and muscle glycogen utilization to be $41 \%$ lower after training compared with before training. It was concluded that the greater utilization of fat in the trained state than that in the untrained state was fuelled by increased lipolysis of intramuscular TG. This conclusion was supported by a study showing a lower turnover of plasma free fatty acids in the trained state (Martin et al. 1993).

\section{UPTAKE OF PLASMA-DERIVED NON-ESTERIFIED FATTY ACIDS}

In the light of the results given previously, the notion that the muscle oxidation rate of plasma-derived free fatty acids depends only on the plasma free fatty acid concentration and blood flow (for references, see Kiens et al. 1993) still seems undisputed. However, there is still a limited amount of information available in this area. Kiens et al. (1993) found no decrease in intramuscular TG during a $2 \mathrm{~h}$ bout of one-leg knee-extension exercise in either the trained or untrained leg of unilaterally bicycle-ergometer-trained subjects. Kiens et al. (1963) speculated that this could be attributable to the small increase in sympatho-adrenal activity during one-leg exercise when compared with two-leg exercise. This sympatho-adrenal activation may have been too low to induce intramuscular lipolysis. In this case it is possible that the increased reliance on fat metabolism observed after training was due to an increased uptake of free fatty acids from the blood.

\section{UTILIZATION OF PLASMA-DERIVED TRIACYLGLYCEROLS}

The small A-V differences for plasma TG over the muscle beds, especially during exercise, has made it difficult to study directly the effect of training on the utilization of plasma-derived TG. Studies on tissue lipoprotein lipase (EC 3.1.1.34; LPL), which is 
located on the intraluminal surface of the capillaries and which catalyses the hydrolysis of intravascular TG, indicate that circulating $\mathrm{TG}$ may be more important in the trained state than in the untrained state. Simsolo et al. (1993) found a marked reduction in muscle LPL ratio with 2 weeks of detraining, whereas that of adipose tissue increased. Simsolo et al. (1993) suggested that the 9-fold increase in the adipose tissue:muscle LPL value with detraining could be seen as a sign of a redirection with detraining of circulating lipid from oxidation in muscle to storage in adipose tissue. The muscle data are in accordance with several other studies showing increases in muscle LPL activity with training (Nikkilä et al. 1978; Svedenhag et al. 1983), but not with all studies (Stubbe et al. 1983). Muscle LPL activity is activated following a single bout of exercise (Lithell et al. 1981) and it has been proposed that the resulting increased clearance of TG from the circulation may provide fatty acids for the restoration of the reduced muscle TG stores induced by exercise (Oscai et al. 1990). Exercise may lead to a decrease in plasma TG which persists for 1-5 d (Oscai et al. 1990).

\section{INTRAMUSCULAR TRIACYLGLYCEROL CONCENTRATION}

As intramuscular TG appear to be an important factor in the sparing of muscle glycogen, one might expect an increased resting level of intramuscular TG in trained muscle. This has not been definitively demonstrated, however, in human muscle. Three studies in which the same subjects were studied before and after training demonstrated an increase in muscle TG of approximately 50\% with training (Morgan et al. 1969; Bylund-Fellenius et al. 1977; Staron et al. 1984). Howald et al. (1985) reported a significant increase in the volume density of intracellular lipid in fast-twitch fibres but not in slow-twitch fibres in an electron micrographic study of endurance training. On the other hand, Hurley et al. (1986) found no significant difference between pre- and post-training muscle TG concentrations in subjects who underwent an intensive 12-week running and cycling training programme. Confounding results have been found in studies on the rat, where both a decrease (Fröberg, 1971; Fröberg et al. 1972) and no change (Gorski \& Kiryluk, 1980 ) in muscle TG concentration in response to training have been noted.

\section{MECHANISMS INVOLVED IN THE INCREASED FAT OXIDATION WITH TRAINING}

If neither the utilization of plasma free fatty acids nor the concentration of intramuscular TG is clearly affected by training, one must conclude that changes responsible for increased fatty acid utilization in the trained state would be related to (1) increased lipolysis of existing intramuscular or plasma TG, (2) increased transport of fatty acids into the mitochondria and/or (3) the increased number of mitochondria within the muscle. It is known that the increased fat oxidation with training is a local effect since it occurs in the trained leg only after one-leg training (Henriksson, 1977; Kiens et al. 1993). Underlying this training response is an increased mitochondrial density and an increased content of mitochondrial enzymes in the aerobically-trained muscle, accompanied by increases in the enzymes involved in activation, transfer into the mitochondria and $\beta$-oxidation of fatty acids (Molé et al. 1971; Holloszy \& Booth, 1976; Saltin \& Gollnick, 1983). As mentioned previously, Holloszy and coworkers (Holloszy \& Booth, 1976) have formulated a hypothetical biochemical mechanism whereby a large concentration of 
mitochondrial oxidative enzymes in trained muscle would lead to a greater reliance on fat metabolism. This adaptation may also include increases in the low-molecular-weight cytosolic fatty acid-binding proteins, which may play an important role in the intracellular transport and targeting of fatty acids (Paulussen \& Veerkamp, 1990), and a change in the activity of regulatory molecules, such as malonyl-CoA (an inhibitor of carnitine acyltransferase I activity (EC 2.3.1.7; Winder et al. 1989)). If these adaptations occur in trained skeletal muscle, they would, at a given exercise intensity, permit the rate of fatty acid oxidation to be higher in the trained muscle than in the untrained muscle, even in the presence of a lower intracellular fatty acid concentration in the trained state. The latter could be secondary to the lower sympatho-adrenal activation in the trained individual (Winder et al. 1978), which, unopposed, would lead to decreased lipolysis of not only adipose tissue TG, but also intramuscular TG. Since $\beta$-receptor mechanisms regulate skeletal muscle TG hydrolysis (Oscai et al. 1990), it is possible that an increased $\beta$-receptor density may at least partially oppose the lower sympatho-adrenal activation in the trained state. However, to date, increased density of $\beta$-receptors has been found in response to training only in the rat (Williams et al. 1984; Buckenmeyer et al. 1990). Martin et al. (1989) found no increase in $\beta$-receptor density in human subjects following 12 weeks of endurance training. Another potentially-more-important factor regulating intramuscular TG utilization may be a training-induced increase in hormone-sensitive lipase (EC 3.1.1.3), the enzyme which hydrolyses intracellular TG into fatty acids (Oscai et al. 1990). No information is currently available, however, on this issue.

Yki-Järvinen et al. (1991) recently presented evidence of a feedback mechanism which serves to maintain a certain rate of cellular fatty acid oxidation under conditions of changing inflow of plasma free fatty acids. This mechanism is supposed to involve stimulation of LPL at times of lowered intracellular free fatty acid concentration, resulting from either insufficient hormone-sensitive lipase activity or lowered plasma free fatty acid concentrations (also, see Oscai et al. 1990). Whether such mechanisms are important in explaining the increased fat reliance in endurance-trained muscle remains to be demonstrated.

\section{PROTEIN METABOLISM}

Proteins normally contribute very little to the total energy expenditure in skeletal muscles (Pettenkofer \& Voit, 1866; Wolfe et al. 1984). Nevertheless, amino acids are catabolized, transaminated, or deaminated during exercise, secondary to the exerciseinduced increase in several metabolic processes, such as hepatic gluconeogenesis and the citric acid cycle, where amino acid-C are utilized. The suppression of protein synthesis during an exercise bout leaves amino acids available for catabolism. The effect of exercise on amino acid concentrations in skeletal muscle and plasma was reviewed recently (Henriksson, 1991).

In the postabsorptive state, skeletal muscle constitutes the major source of circulating amino acids in the body. In spite of this, very little information is available concerning the influence of endurance training on muscle production and release of individual amino acids, although some positive effects of training were indicated by a recent study in perfused rat muscle (Hood \& Terjung, 1994). During endurance exercise, branchedchain amino acids (BCAA) are taken up by the muscle (Wagenmakers et al. 1990), and during prolonged exercise this may lead to significant reductions in the plasma BCAA 
level. There is evidence that the BCAA may be only partly metabolized within the muscle to form branched-chain ketoacids and short-chain acylcarnitines, which are released into the circulation and transported to the liver for further oxidation. The amino group thereby liberated may be released from muscle in the form of glutamine or alanine (Ji et al. 1987). However, a significant activation of the muscle branched-chain 2-oxoacid dehydrogenase ( $E C$ 1.2.4.4) complex has been noted in long-term exercise (Wagenmakers et al. 1990). The drainage of citric acid cycle C by BCAA transamination in combination with a reduced inflow from glycolysis has been suggested to be a factor limiting the rate of fatty acid oxidation during prolonged exhaustive exercise (Wagenmakers et al. 1990). Current findings indicate that the activation of BCAA metabolism with prolonged exercise occurs to a greater extent in trained individuals than in untrained individuals (Dohm et al. 1977; Henriksson, 1991). Increased BCAA availability or decreased carbohydrate availability results in increased BCAA metabolism with higher plasma concentrations of $\mathrm{NH}_{3}$ and glutamine (MacLean \& Graham, 1993) during exercise.

We have found some evidence that trained individuals may have higher basal amino acid concentrations in skeletal muscle and plasma than untrained individuals (Henriksson, 1991). In the literature, there is only one reference to a possible difference in this direction (Einspahr \& Tharp, 1989). These investigators found that the trained subjects had significantly higher plasma concentrations of leucine $(41 \%)$, isoleucine $(27 \%)$ and tyrosine $(23 \%)$. Evidently, more research is needed to confirm these preliminary findings and, if confirmed, to determine the underlying mechanisms responsible for these muscular adaptations.

\section{INSULIN ACTION}

With an acute bout of exercise, in addition to the direct stimulation of muscle glucose uptake (Nesher et al. 1985; Wallberg-Henriksson et al. 1988), the sensitivity of muscle glucose transport to insulin is increased (Richter et al. 1982; Zorzano et al. 1986; Cartee et al. 1989). Both the direct and insulin-mediated effects of contraction are sustained into the post-exercise period. The direct effect is reversed within a few hours (Young et al. 1987), whereas the enhanced insulin sensitivity as a result of an acute exercise bout (which is not detectable until the direct effect has been partially reversed) lasts longer (usually 1-2 d; Wallberg-Henriksson et al. 1988). The rate of reversal varies and seems to depend on the refilling of glycogen stores (Gulve et al. 1990). However, it is unlikely that the reversal of insulin action is linked only to glycogen replenishment per se, since an enhanced glycogen synthesis was found in response to insulin even when the glycogen concentration in the muscle had returned to control levels (Langfort et al. 1988; Richter et al. 1989).

\section{Effect of training}

Consistent with the reports showing increases in muscle GLUT4 protein with training (see p. 128), several studies have shown that endurance training results in an increased insulin sensitivity as well as responsiveness in skeletal muscle, whereas insulin resistance accompanies inactivity (for references, see Sinacore \& Gulve, 1993). In healthy individuals these changes in insulin action are not usually accompanied by similar 
changes in glucose tolerance (Rogers et al. 1990), since the plasma insulin level during a glucose-tolerance test changes in a reciprocal manner relative to the changes in insulin action.

Most investigations performed to date have indicated that the enhanced glucose uptake at submaximal insulin concentrations (insulin sensitivity) noted in trained individuals is not a true training-induced adaptation but merely an effect of the last exercise bout, since it is lost within a few days following cessation of training (King et al. 1988; Mikines et al. 1989b; Nagasawa et al. 1990; Rogers et al. 1990). Whether the improved insulin action in skeletal muscle is a true adaptation to training or not, the results demonstrate the importance of regularly performed exercise to protect against the development of insulin resistance, for example with ageing, or to improve insulin action in such pathological states as obesity and type II diabetes. It may also be noted that not all types of exercise are associated with increased insulin action (Kirwan et al. 1992; Doyle et al. 1993).

\section{MECHANISMS FOR THE ENHANCED INSULIN ACTION WITH ENDURANCE TRAINING}

Two important underlying factors are likely to be the training-induced increased number of glucose transporters and the higher muscle glycogen synthase activity in trained individuals than in untrained ones (see pp. 128, 130). Physical training may also lead to changes in body composition with a reduction in fat and an increase in muscle tissue, which leads to enhanced whole-body glucose disposal (Yki-Järvinen \& Koivisto, 1983). Other factors which could be important in this respect, but which have not yet been subjected to closer examination, include insulin-induced blood-flow changes (Laakso et al. 1990; Hickner et al. 1994), the fibre-type profile (Wade et al. 1990; Pagliassotti et al. 1993), the fatty acid composition of muscle sarcolemma (Borkman et al. 1993), the concentration of amylin (Young et al. 1993), the hexosamine pathway (Marshall et al. 1991) and glycogenin (Smythe \& Cohen, 1991).

\section{CONCLUDING REMARKS}

This research field is presently in an active phase and the involvement of several previously unrecognized factors, such as insulin-like growth factor 1 , have only recently started to be revealed. In addition, as in most other fields, recombinant DNA techniques are being used to explore the genetic mechanisms behind the different adaptive changes. Still, training-induced adaptations in several important metabolic systems await fuller exploration. These include the utilization of plasma-derived glucose during contractions, muscle insulin sensitivity, the utilization of plasma-derived NEFA and the utilization of endogenous and plasma-derived TG.

\section{REFERENCES}

Ahlborg, G., Felig, P., Hagenfeldt, L., Hendler, R. \& Wahren, J. (1974). Substrate turnover during prolonged exercise in man: splanchnic and leg metabolism of glucose, free fatty acids and amino acids. Journal of Clinical Investigation 53, 1080-1090.

Ahlborg, G., Wahren, J. \& Felig, P. (1986). Splanchnic and peripheral glucose and lactate metabolism during and after prolonged arm exercise. Journal of Clinical Investigation 77, 690-699. 
BeltrandelRio, H. \& Wilson, J. E. (1992). Coordinated regulation of cerebral glycolytic and oxidative metabolism, mediated by mitochondrially bound hexokinase dependent on intramitochondrially generated ATP. Archives of Biochemistry and Biophysics 296, 667-677.

Bergström, J., Hermansen, L., Hultman, E. \& Saltin, B. (1967). Diet, muscle glycogen and physical performance. Acta Physiologica Scandinavica 71, 140-150.

Borkman, M., Storlien, L. H., Pan, D. A., Jenkins, A. B., Chisholm, D. J. \& Campbell, L. V. (1993). The relation between insulin sensitivity and the fatty-acid composition of skeletal-muscle phospholipids. New England Journal of Medicine 328, 238-244.

Buckenmeyer, P. J., Goldfarb, A. H., Partilla, J. S., Pineyro, M. A. \& Dax, E. M. (1990). Endurance training, not acute exercise, differentially alters $\beta$-receptors and cyclase in skeletal fiber types. American Journal of Physiology 258, E71-E77.

Bylund-Fellenius, A. C., Bjurö, T., Cederblad, J., Holm, K., Lundholm, K., Sjöström, M., Ängqvist, K. A. \& Scherstén, T. (1977). Physical training in man. Skeletal muscle metabolism in relation to muscle morphology and running ability. European Journal of Applied Physiology and Occupational Physiology 36, 151-169.

Carlson, L. A., Ekelund, L.-G. \& Fröberg, S. O. (1971). Concentration of triglycerides, phospholipids and glycogen in skeletal muscle and of free fatty acids and beta-hydroxybutyric acid in blood in man in response to exercise. European Journal of Clinical Investigation 1, 248.

Cartee, G. D., Young, D. A., Sleeper, M. D., Zierath, J., Wallberg-Henriksson, H. \& Holloszy, J. O. (1989). Prolonged increase in insulin-stimulated glucose transport in muscle after exercise. American Journal of Physiology 256, E494-E499.

Coggan, A. R., Kohrt, W. M., Spina, R. J., Bier, D. M. \& Holloszy, J. O. (1990). Endurance training decreases plasma glucose turnover and oxidation during moderate-intensity exercise in men. Journal of Applied Physiology 68, 990-996.

Craig, B. W. (1993). The influence of fructose feeding on physical performance. American Journal of Clinical Nutrition 58, Suppl., 815S-819S.

Dela, F., Handberg, A., Mikines, K. J., Vinten, J. \& Galbo, H. (1993). GLUT 4 and insulin receptor binding and kinase activity in trained human muscle. Journal of Physiology 469, 615-624.

Devlin, J. T. \& Horton, E. S. (1985). Effects of prior high-intensity exercise on glucose metabolism in normal and insulin-resistant men. Diabetes 34, 973-979.

Dimitriadis, G., Parry-Billings, M., Bevans, S., Dunger, D., Piva, T., Krause, U., Wegener, G. \& Newsholme, E. A. (1992). Effects of insulin-like growth factor I on the rates of glucose transport and utilization in rat skeletal muscle in vitro. Biochemical Journal 285, 269-274.

Dohm, G. L., Hecker, A. L., Brown, W. E., Klain, G. J., Puente, F. R., Askew, E. W. \& Beecher, G. R. (1977). Adaptation of protein metabolism to endurance training. Biochemical Journal 164, 705-708.

Douen, A. G., Ramlal, T., Klip, A., Young, D. A., Cartee, G. D. \& Holloszy, J. O. (1989). Exercise-induced increase in glucose transporters in plasma membranes of rat skeletal muscle. Endocrinology 124, 449-454.

Doyle, J. A., Sherman, W. M. \& Strauss, R. L. (1993). Effects of eccentric and concentric exercise on muscle glycogen replenishment. Journal of Applied Physiology 74, 1848-1855.

Ebeling, P., Bourey, R., Koranyi, L., Touminen, J. A., Groop, L. C., Henriksson, J., Mueckler, M., Sovijärvi, A. \& Koivisto, V. A. (1993). Mechanism of enhanced insulin sensitivity in athletes. Increased blood flow, muscle glucose transport protein (glut-4) concentration, and glycogen synthase activity. Journal of Clinical Investigation 92, 1623-1631.

Einspahr, K. J. \& Tharp, G. (1989). Influence of endurance training on plasma amino acid concentrations in humans at rest and after intense exercise. International Journal of Sports Medicine 10, 233-236.

Fitts, R. H., Booth, F. W., Winder, W. W. \& Holloszy, J. O. (1975). Skeletal muscle respiratory capacity, endurance, and glycogen utilization. American Journal of Physiology 228, 1029-1033.

Fröberg, S. O. (1971). Effects of training and acute exercise in trained rats. Metabolism 20, 1044-1051.

Fröberg, S. O. \& Mossfeldt, F. (1971). Effect of prolonged strenuous exercise on the concentration of triglycerides, phospholipids and glycogen in muscle of man. Acta Physiologica Scandinavica 82, 167.

Fröberg, S. O., Östman, I. \& Sjöstrand, N. O. (1972). Effects of training on esterified fatty acids and carnitine in muscle and on lipolysis in adipose tissue in vitro. Acta Physiologica Scandinavica 86, 166-174.

Goodyear, L. J., Hirschman, M. F., King, P. A., Horton, E. D., Thompson, C. M. \& Horton, E. S. (1990). Skeletal muscle plasma membrane glucose transport and glucose transporters after exercise. Journal of Applied Physiology 68, 193-198.

Gorski, J. \& Kiryluk, T. (1980). The post-exercise recovery of triglycerides in rat tissues. European Journal of Applied Physiology and Occupational Physiology 45, 33-41. 
Green, H. J., Smith, D., Murphy, P. \& Fraser, I. (1990). Training-induced alterations in muscle glycogen utilization in fibre-specific types during prolonged exercise. Canadian Journal of Physiology and Pharmacology 68, 1372-1376.

Griffiths, A. J., Hưmphreys, S. M., Clark, M. L. \& Frayn, K. N. (1994). Forearm substrate utilization during exercise after a meal containing both fat and carbohydrate. Clinical Science 86, 169-175.

Gulve, E. A., Cartee, G. D., Zierath, J. R., Corpus, V. M. \& Holloszy, J. O. (1990). Reversal of enhanced muscle glucose transport after exercise; roles of insulin and glucose. American Journal of Physiology 259, E685-E691.

Havel, R. J., Naimark, A. \& Borchgrevink, C. F. (1963). Turnover rate and oxidation of free fatty acids of blood plasma in man during exercise: studies during continuous infusion of palmitate- $1^{-14} \mathrm{C}$. Journal of Clinical Investigation 42, 1054-1063.

Havel, R. J., Pernow, B. \& Jones, N. L. (1967). Uptake and release of free fatty acids and other metabolites in the legs of exercising men. Journal of Applied Physiology 23, 90-99.

Häggmark, T. (1978). A study of morphologic and enzymatic properties of the skeletal muscles after injuries and immobilization in man. Doctoral Dissertation Thesis, Karolinska Institutet, Stockholm.

Henriksson, J. (1977). Training induced adaptation of skeletal muscle and metabolism during submaximal exercise. Journal of Physiology 270, 661-675.

Henriksson, J. (1991). Effect of exercise on amino acid concentrations in skeletal muscle and plasma. Journal of Experimental Biology 160, 149-165.

Hermansen, L., Hultman, E. \& Saltin, B. (1967). Muscle glycogen during prolonged severe exercise. Acta Physiologica Scandinavica 71, 129-139.

Hickner, R. C., Ungerstedt, U. \& Henriksson, J. (1994). Regulation of skeletal muscle blood flow during acute insulin-induced hypoglycemia in the rat. Diabetes $43,1340-1344$.

Holloszy, J. O. (1988). Metabolic consequences of endurance exercise training. Exercise, Nutrition and Energy Metabolism, p. 116 [E. S. Horton and R. L. Terjung, editors]. New York: Macmillan.

Holloszy, J. O. \& Booth, F. W. (1976). Biochemical adaptations to endurance exercise in muscle. Annual Reviews of Physiology 38, 273-291.

Hood, D. A. \& Terjung, R. L. (1994). Endurance training alters alanine and glutamine release from muscle during contractions. FEBS Letters $340,287-290$.

Howald, H., Hoppeler, H., Claassen, H., Mathieu, O. \& Straub, R. (1985). Influences of endurance training on the ultrastructural composition of the different muscle fiber types in humans. Pflügers Archiv 403, $369-376$.

Hurley, B. F., Nemeth, P. M., Martin, W. H., Hagberg, J. M., Dalsky, G. P. \& Holloszy, J. O. (1986). Muscle triglyceride utilization during exercise: effect of training. Journal of Applied Physiology 60, 562-567.

Jansson, E. \& Kaijser, L. (1987). Substrate utilization and enzymes in skeletal muscle of extremely endurance-trained men. Journal of Applied Physiology 62, 999-1005.

Ji, L. L., Miller, R. H., Nagle, F. J., Lardy, H. A. \& Stratman, F. W. (1987). Amino acid metabolism during exercise in trained rats: the potential role of carnitine in the metabolic fate of branched-chain amino acids. Metabolism 36, 748-752.

Jones, N. L., Heigenhauser, G. J. F., Kuksis, A., Matos, C. G., Sutton, J. R. \& Toews, C. J. (1980). Fat metabolism in heavy exercise. Clinical Science 59, 469-478.

Kern, M. , Tapscott, E. B., Downes, D. L., Frisell, W. R. \& Dohm, G. L. (1990). Insulin resistance induced by high-fat feeding is only partially reversed by exercise training. Pflügers Archiv 417, 79-83.

Kiens, B., Essén-Gustavsson, B., Christensen, N. J. \& Saltin, B. (1993). Skeletal muscle substrate utilization during submaximal exercise in man: effect of endurance training. Journal of Physiology 469, 459-478.

King, D. S., Dalsky, G. P., Clutter, W. E., Young, D. A., Staten, M. A., Cryer, P. E. \& Holloszy, J. O. (1988). Effects of exercise and lack of exercise on insulin sensitivity and responsiveness. Journal of Applied Physiology 64, 1942-1946.

Kirwan, J. P., Hickner, R. C., Yarasheski, K. E., Kohrt, W. M., Wiethop, B. V. \& Holloszy, J. O. (1992). Eccentric exercise induces transient insulin resistance in healthy individuals. Journal of Applied Physiology 72, 2197-2202.

Laakso, M., Edelman, S. V., Olefsky, J. M., Brechtel, G., Wallace, P. \& Baron, A. D. (1990). Kinetics of in vivo muscle insulin-mediated glucose uptake in human obesity. Diabetes 39, 965-974.

Langfort, J., Budohoski, L. \& Newsholme, E. A. (1988). Effect of various types of acute exercise and exercise training on the insulin sensitivity of rat soleus muscle measured in vitro. Pflügers Archiv 412, 101-105.

Lithell, H., Cedermark, M., Fröberg, J., Tesch, P. \& Karlsson, J. (1981). Increase of lipoprotein-lipase activity in skeletal muscle during heavy exercise - relation to epinephrine excretion. Metabolism 30, 1130-1138. 
MacLean, D. A. \& Graham, T. E. (1993). Branched-chain amino acid supplementation augments plasma ammonia responses during exercise in humans. Journal of Applied Physiology 74, 2711-2717.

Mackie, B. G., Dudley, G. A., Kaciuba-Uscilko, H. \& Terjung, R. L. (1980). Uptake of chylomicron triglycerides by contracting skeletal muscles in rats. Journal of Applied Physiology 49, 851-855.

Marshall, B. A., Ren, J. M., Johnson, D. W., Gibbs, E. M., Lillquist, J. S., Soeller, W. C., Holloszy, J. O. \& Mueckler, M. (1993). Germline manipulation of glucose homeostasis via alteration of glucose transporter levels in skeletal muscle. Journal of Biological Chemistry 268, 18442-18445.

Marshall, S., Garvey, W. T. \& Traxinger, R. R. (1991). New insights into the metabolic regulation of insulin action and insulin resistance: role of glucose and amino acids. FASEB Journal 5, 3031-3036.

Martin, W. H., Dalsky, G. P., Hurley, B. F., Matthews, D. E., Bier, D. M., Hagberg, J. M., Rogers, M. A., King, D. S. \& Holloszy, J. O. (1993). Effect of endurance training on plasma free fatty acid turnover and oxidation during exercise. American Journal of Physiology 265, E708-E714.

Martin, W. H. I., Coggan, A. R., Spina, R. J. \& Saffitz, J. E. (1989). Effects of fiber type and training and $\beta$-adrenoceptor density in human skeletal muscle. American Journal of Physiology 257, E736-E742.

Mendenhall, L. A., Swanson, S. C., Habash, D. L. \& Coggan, A. R. (1994). Ten days of exercise training reduces glucose production and utilization during moderate-intensity exercise. American Journal of Physiology 266, E136-E143.

Mikines, K. J., Sonne, B., Farrell, P. A., Tronier, B. \& Galbo, H. (1989a). Effect of training on the dose-response relationship for insulin action in men. Journal of Applied Physiology 66, 695-703.

Mikines, K. J., Sonne, B., Tronier, B. \& Galbo, H. (1989b). Effects of acute exercise and detraining on insulin action in trained men. Journal of Applied Physiology 66, 704-711.

Molé, P. A., Oscai, L. B. \& Holloszy, J. O. (1971). Adaptation of muscle to exercise. Increase in levels of palmityl CoA synthetase, carnitine palmityltransferase, and palmityl CoA dehydrogenase, and in the capacity to oxidize fatty acids. Journal of Clinical Investigation 50, 2323-2330.

Morgan, T. E., Short, F. A. \& Cobb, L. A. (1969). Effect of long-term exercise on skeletal muscle lipid composition. American Journal of Physiology 216, 82-86.

Nagasawa, J., Sato, Y. \& Ishiko, T. (1990). Effect of training and detraining on in vivo insulin sensitivity. International Journal of Sports Medicine 11, 107-110.

Nesher, R., Karl, I. E. \& Kipnis, D. M. (1985). Dissociation of effects of insulin and contraction on glucose transport in rat epitrochlearis muscle. American Journal of Physiology 249, C226-C232.

Nikkilä, E. A. \& Konttinen, A. (1962). Effect of physical activity on postprandial levels of fats in serum. Lancet 1, 1151-1154.

Nikkilä, E. A., Taskinen, M.-R., Rehunen, S. \& Härkönen, M. (1978). Lipoprotein lipase activity in adipose tissue and skeletal muscle of runners: relation to serum lipoproteins. Metabolism 27, 1661-1671.

O'Brien, M. J., Viguie, C. A., Mazzeo, R. S. \& Brooks, G. A. (1993). Carbohydrate dependence during marathon running. Medicine and Science in Sports and Exercise 25, 1009-1017.

Oscai, L. B., Essig, D. A. \& Palmer, W. K. (1990). Lipase regulation of muscle triglyceride hydrolysis. Journal of Applied Physiology 69, 1571-1577.

Pagliassotti, M. J., Shahrokhi, K. A. \& Hill, J. O. (1993). Skeletal muscle glucose metabolism in obesity-prone and obesity-resistant rats. American Joumal of Physiology 264, R1224-R1228.

Paulussen, R. J. A. \& Veerkamp, J. H. (1990). Intracellular fatty-acid-binding proteins. Characteristics and function. Subcellular Biochemistry, p. 175 [H. J. Hilderson, editor]. New York: Plenum Press.

Pettenkofer, M. \& Voit, C. (1866). Untersuchungen über den Stoffverbrauch des normalen Menschen (Investigations on the fuel utilization in normal individuals). Zeitschrift für Biologie 2, 537.

Richter, E. A., Garetto, L. P., Goodman, M. N. \& Ruderman, N. B. (1989). Muscle glucose metabolism following exercise in the rat. Increased sensitivity to insulin. Journal of Clinical Investigation 69, 785-793.

Robinson, R., Robinson, L. J., James, D. E. \& Lawrence, J. C. Jr (1993). Glucose transport in L6 myoblasts overexpressing GLUT1 and GLUT4. Journal of Biological Chemistry 268, 22119-22126.

Rogers, M. A., King, D. S., Hagberg, J. M., Ehsani, A. A. \& Holloszy, J. O. (1990). Effect of 10 days of physical inactivity on glucose tolerance in master athletes. Journal of Applied Physiology 68, 1833-1837.

Saltin, B. \& Gollnick, P. D. (1983). Skeletal muscle adaptability: significance for metabolism and performance. Handbook of Physiology - Skeletal Muscle, p. 555 [L. D. Peachy, R. H. Adrian and S. R. Geiger, editors]. Bethesda, MD: American Physiology Society.

Saltin, B., Nazar, D. L., Costill, D. L., Stein, E., Jansson, E., Essén, B. \& Gollnick, P. (1976). The nature of the training response: peripheral and central adaptations to one-legged exercise. Acta Physiologica Scandinavica 96, 289-305.

Sherman, W. M. \& Costill, D. L. (1984). The marathon: dietary manipulation to optimize performance. American Journal of Sports Medicine 12, 44-51. 
Simsolo, R. B., Ong, J. M. \& Kern, P. A. (1993). The regulation of adipose tissue and muscle lipoprotein lipase in runners by detraining. Journal of Clinical Investigation 92, 2124-2130.

Sinacore, D. R. \& Gulve, E. A. (1993). The role of skeletal muscle in glucose transport, glucose homeostasis, and insulin resistance: Implications for physical therapy. Physical Therapy 73, 878-891.

Smythe, C. \& Cohen, P. (1991). The discovery of glycogenin and the priming mechanism for glycogen biogenesis. European Journal of Biochemistry 200, 625-631.

Staron, R. S., Hikida, R. S., Hagerman, F. C., Dudley, G. A. \& Murray, T. F. (1984). Human skeletal muscle fiber type adaptability to various workloads. Journal of Histochemistry and Cytochemistry 32, 146-152.

Sternlicht, E., Barnard, R. J. \& Grimditch, G. K. (1989). Exercise and insulin stimulate skeletal muscle glucose transport through different mechanisms. American Journal of Physiology 256, E227-E230.

Stubbe, I., Hansson, P., Gustafson, A. \& Nilsson-Ehle, P. (1983). Plasma lipoproteins and lipolytic enzymes activities during endurance training in sedentary men: changes in high-density lipoprotein subfractions and composition. Metabolism 32, 1120-1128.

Svedenhag, J., Lithell, H., Juhlin-Dannfelt, A. \& Henriksson, J. (1983). Increased skeletal muscle lipoprotein lipase following endurance training in man. Atherosclerosis 49, 203-207.

Van Houten, D. R., Davis, J. M., Meyers, D. M. \& Dursine, J. L. (1992). Altered cellular distribution of hexokinase in skeletal muscle after exercise. International Journal of Sports Medicine 13, 436-438.

Vergauwen, L., Hespel, P. \& Richter, E. A. (1994). Adenosine receptors mediate synergistic stimulation of glucose uptake and transport by insulin and by contractions in rat skeletal muscle. Journal of Clinical Investigation 93, 974-981.

Vestergaard, H., Andersen, P. H., Lund, S., Schmitz, O., Junker, S. \& Pedersen, O. (1994). Pre- and posttranslational upregulation of muscle-specific glycogen synthase in athletes. American Journal of Physiology 266, E92-E101.

Wade, A. J., Marbut, M. M. \& Round, J. M. (1990). Muscle fibre type and aetiology of obesity. Lancet 335, $805-808$.

Wagenmakers, A. J., Coakley, J. H. \& Edwards, R. H. T. (1990). Metabolism of branched-chain amino acids and ammonia during exercise: clues from McArdle's disease. International Journal of Sports Medicine 11, S101-S113.

Wahren, J., Felig, P., Ahlborg, G. \& Jorfeldt, L. (1971). Glucose metabolism during leg exercise in man. Journal of Clinical Investigation 50, 2715-2725.

Wallberg-Henriksson, H., Constable, S. H., Young, D. A. \& Holloszy, J. O. (1988). Glucose transport into rat skeletal muscle: interaction between exercise and insulin. Journal of Applied Physiology 65, 909-913.

Williams, R. S., Caron, M. G. \& Daniel, K. (1984). Skeletal muscle $\beta$-adrenergic receptors: variations due to fiber type and training. American Journal of Physiology 246, E160-E167.

Winder, W. W., Arogyasami, J., Barton, R. J., Elayan, I. M. \& Vehrs, P. R. (1989). Muscle malonyl-CoA decreases during exercise. Journal of Applied Physiology 67, 2230-2233.

Winder, W. W., Hagberg, J. M., Hickson, R. C., Ehsani, A. A. \& McLane, J. A. (1978). Time course of sympathoadrenal adaptation to endurance exercise training in man. Journal of Applied Physiology $\mathbf{4 5}$, 370-374.

Wolfe, R. R., Wolfe, M. H., Nadel, E. R. \& Shaw, J. H. F. (1984). Isotopic determination of amino acid urea interactions in exercise in humans. Journal of Applied Physiology 56, 221-229.

Yki-Järvinen, H. \& Koivisto, V. A. (1983). Effects of body composition on insulin sensitivity. Diabetes 32, 965-969.

Yki-Järvinen, H., Puhakainen, I., Saloranta, C., Groop, L. \& Taskinen, M.-R. (1991). Demonstration of a novel feedback mechanism between FFA oxidation from intracellular and intravascular sources. American Journal of Physiology 260, E680-E689.

Young, A. A., Carlo, P., Smith, P., Wolfe-Lopez, D., Pittner, R., Wang, M. W. \& Rink, T. (1993). Evidence for release of free glucose from muscle during amylin-induced glycogenolysis in rats. FEBS Letters 334, 317-321.

Young, D. A., Wallberg-Henriksson, H., Sleeper, M. D. \& Holloszy, J. O. (1987). Reversal of the exercise-induced increase in muscle permeability to glucose. American Journal of Physiology 253, E331-E335.

Zorzano, A., Balon, T. W., Goodman, M. N. \& Ruderman, N. B. (1986). Additive effects of prior exercise and insulin on glucose and AIB uptake by rat muscle. American Journal of Physiology 251, E21-E26. 